\title{
Schools as workplaces: \\ Intersectional regimes of inequality
}

Johanna S. Quinn and Myra Marx Ferree

\section{Draft prepared for Gender, Work and Organizations Special issue commemorating Joan Acker}

October 24, 2017

Support for this work was provided by the National Academy of Education/Spencer Dissertation Fellowship Program and by the Graduate School and the Office of the Vice Chancellor for Research and Graduate Education at the University of Wisconsin-Madison with funding from the Wisconsin Alumni Research Foundation. 


\title{
Schools as workplaces: Intersectional regimes of inequality
}

\begin{abstract}
Joan Acker extended her 1990 brilliant and path-breaking article, "Gender, Jobs, Bodies," to address the intersectional effects of gender, race and class as "inequality regimes" in her 2006 article of that name. This research picks up her challenge to see embodied workers holding jobs in organizations structured simultaneously and interactively by gender, race and class processes. Rather than studying a corporate regime in which the actors are managers, supervisors and workers, this study looks at the organizational interactions among teachers and paraprofessionals in one large, urban and unionized school district in the U.S. We look at skill, care and respect as three dimensions of interaction embedded in the occupational demands and specific job requirements of teachers and paraprofessionals, and some of the tensions this regime produces between the largely White teachers and the women of color who are the paraprofessionals. By highlighting the mostly invisible racialized work of supporting the moral worth of students and staff, we extend understandings of skill and care beyond a binary model.
\end{abstract}




\section{Schools as workplaces: Intersectional regimes of inequality}

Public school systems comprise one of the largest job sectors in the United States, employing over six million workers each year. A considerable and growing proportion of Americans, the majority of whom are women, work in public schools (Ingersoll, Merrill, \& Stuckey, 2014). School jobs vary greatly in terms of status and reward — from low-paying cafeteria work to high-paying principalships — and are segmented by gender and race. While the racial and class divisions students face in U.S. schools are well documented (Frankenberg \& Orfield, 2012; Orfield \& Lee, 2005), the processes that stratify school employees in these workplaces are much less studied.

Joan Acker's approach to "inequality regimes" as occupationally organized forms of social interaction pays attention not only to gender but also to multiple dimensions of difference, including particularly class and race, but also sexualities and abilities(2006). In jobs, intersectional status beliefs about differences in work and workers are salient and readily reinforced, contested, and observed (Ridgeway, 2014). As workplaces, schools engage in the care and socialization of children, but also organize the relationships among the adults doing their jobs. What we know about school workplaces is almost completely limited to teachers and principals, yet teachers' aides (also known as paraprofessionals or paras) and support staff account for more than 42 percent of school employees (Snyder, de Brey, \& Dillow, 2016). Limiting studies of school workplaces to the experiences of teachers (Apple, 1986; Ingersoll, 2003; Lortie, 1975) leaves out integral members of school communities, circumscribes the relational aspect of schooling to student-teacher relationships, makes workplace hierarchy less salient, and overlooks much of the work performed by minority women in schools. Just as the 
work of managers is not only done by those whose work title is manager (Acker, 2006, p. 449), the work of teaching is not only done by those who are paid as teachers, but also by a large number of paraprofessionals.

In examining paraprofessionals and their jobs, we draw on the intersectional framework that brings race, class, and gender together as multi-level processes (Choo \& Ferree, 2010; Crenshaw, 1989; Glenn, 1999). Following Acker's 2006 lead, we look to schools as sites of inequality regimes, that is, the "loosely related practices, process, actions and meanings that result in and maintain class, gender and race inequalities" ( p. 443). This means drawing attention to both how paras are organizationally situated relative to teachers in the hierarchy of jobs in U.S. schools and how their work is organized by and through assumptions about what formal education is supposed to be about and what labor paras are to provide.

We identify two familiar dimensions of interactional labor associated with teaching as a job: having and transmitting skills understood as formal educational qualifications; caring for students and promoting their socio-emotional growth, understood as nurturance. We add a third dimension, that of translating the differences among students and staff into relations of respect, both for others and for oneself, which we understand as a racialized labor of boundary work around claims to moral worth and citizenship. Since racial subordination is a significant part of the organization of American public schools, "race work" that reproduces and contests moral boundaries among groups is an integral part of the inequality regime. By developing racial pride in students and bridging racial understandings among staff, paras provide the labor that translates diversity into dignity. Hierarchies of moral worth that demand such race work intersect with the more acknowledged hierarchies of class (organizationally expressed as formal educational qualifications) and gender (expressed in the rule-bound management of professional work). 
We further argue that the skill, care and respect dimensions of public school teaching are associated with status markers applied to all workers in contemporary America: class is defined in terms of a meritocratic system in which higher education credentials signal greater competence and more social value, especially but not exclusively expressed in higher pay; gender is defined in terms of women's supposed greater interest and competence in nurturance, whether or not compensated directly with a paycheck; race is defined in terms of the greater respect afforded to those who are recognized as White, particularly in experiencing fewer challenges to their belonging as morally worthy citizens. This inequality regime requires "race work" on the job in order to include the perspectives and needs of students and staff of color. The workforce of paraprofessionals and teachers, both organizational categories that are coded female, both draws on and reproduces class, gender and race as matters of how work is to be done, by whom, and for whom.

\section{Theorizing school work through intersectionality}

While gender is embedded in labor relations of all kinds, the job of educating students brings intersectional demands for care work to the fore. Care work is "labor that contributes to the well-being or development of other people that is often face-to-face and requires skills in interaction" (Dwyer, 2013, p. 391). Race, class, and gender are all integral to how caring occupations are structured, experienced, and performed. In the U.S., college educated (mostly White) women dominate the higher paying care work job of teaching, while mostly minority women are found in the less-credentialed forms of care work such as nurses' and teachers' aides (Glenn, 1992). In teaching, the persistent association of good teaching with mothering circumscribes the behavior of both men and women teachers (Collins, 1998; Fisher, 2001; James, 2010). Young, working-class, early childhood teachers in England report that becoming a good 
teacher requires performances of wholesomeness. When interacting with parents they pretend that they do not have lives outside of the school where they smoke, drink, or have sex, but instead emphasize caring for other people's children as the totality of their being (Vincent \& Braun, 2012). Likewise, many male teachers describe feeling caught between needing or wanting to care for students and the fear that their caring behavior will be viewed as sexually predatory or out-of-step with masculine requirements to be strong and detached. This is a particularly difficult arrangement for Black men to navigate (Brockenbrough, 2012; Hansen \& Mulholland, 2005; Lynn, 2006).

Skill, like care, is also a highly gendered and racialized concept. While skill is often defined in terms of a job's perceived complexity and measured using years of education and experience, these are not straightforward objective measures. (Acker, 1990; England, 1992; England, Budig, \& Folbre, 2002; Steinberg, 1990). Relational skills are most often overlooked in evaluation frameworks, which is one reason jobs requiring interaction and communication with people consistently suffer a wage penalty (England, 2005; Kilbourne, England, Farkas, Beron, \& Weir, 1994). Women workers have sought to define their work as skilled by waging professionalization campaigns, with the result that tasks viewed as unskilled were shifted onto workers with less formal education and training (Duffy, 2011). The movements to professionalize nursing and teaching created advantages for White women at the expense of women of color since 'the division between 'skilled' and 'unskilled' jobs is exactly where the racial division typically falls" (Glenn, 1992, p. 37).

But adding the demand for care to the structural demand for educational qualifications as evidence of skill as a teacher does not fully define the intersectional organization of inequality in school systems. An additional dimension is establishing the moral worth of each individual, 
which Lamont (2000) calls “boundary work." She explores how workers construct a sense of self-worth, and how they view social hierarchy as a result of the moral distinctions they make between themselves and others. Public schools in particular are charged with the social responsibility of creating good citizens, respectable and respectful members of society, which means both affirming the dignity of the individual and reproducing social hierarchies. Bringing this moral dimension of boundary work into Acker's understanding of inequality regimes highlights the reproduction and contestation of a racialized understanding of inclusion in citizenship as part of the work that public schools perform.

The inequality regime of U.S. school systems reproduces racial segregation both horizontally, between different districts, drawn increasingly narrowly to insulate White families from sharing resources with students of color, and vertically by maintaining disproportionate numbers of White administrators and teachers even in the districts with a large majority of racialized "minority" students. When schools are viewed as workplaces, it becomes more apparent that the inequality regime that defines skill in terms of credentials and care in terms of feminized nurturance also produces moral worth in terms of racialized evaluation, three dimensions that are intersectionally constitutive of both jobs and identities. Respect may be denied Black men, who are often evaluated as not possessing "soft skills" (Moss \& Tilly, 1996), while Black women are stereotyped as "bad mothers" (Kennelly, 1999) and all minority workers may have to perform "racial tasks" to obscure their racial identity for the sake of being acceptable to Whites (Wingfield \& Alston, 2013).

Claims to moral worth thus also imply resistance to the reproduction of racial inequality. Such resistance can encompass claims to unrecognized skills and contributions that women of color make in schools. Black feminist scholars such as Gloria Ladson-Billings, Adrienne Dixon, 
and Jeannine Dingus, describe the unique ways Black women teachers combine deep empathetic caring with tough discipline along with high expectations to successfully educate students (Dingus, 2008; Dixson, 2003; Dixson \& Dingus, 2008; Foster, 1993; Ladson-Billings, 1994). These teachers' pedagogies incorporate political activism with a duty to remain connected to community (Dixson \& Dingus, 2008, p. 818). In U.S. schools, however, women of color are more likely to be paraprofessionals than credentialed teachers, and this structural difference in how race interacts with gender in credentialing, hiring, organizing work, and assigning rewards matters to the paras, their relationships with teachers, and their ability to help children learn.

In sum, as an inequality regime, gender, race, and class together determine the structure of teaching as an occupation by setting limits on the constitution of the workforce, defining the rewards and career trajectories available to workers, and institutionalizing the organization of tasks in more or less hierarchical ways. At the micro-level, workers are held accountable to the practice of racialized femininities and masculinities, thereby reproducing (and contesting) gender, race, and class in interaction (Martin, 2003; Pierce, 1995). Acker's framing of inequality regimes connects the organization of skill and care with the particular practices and processes of schools as organizations, and we add attention to claims for moral worth to her model. In all three dimensions, both teachers and paraprofessionals with racial, class and gender statuses vie for recognition and rewards through interactions with each other and with the children for whom they are responsible.

\section{Methodology}

This paper is drawn from a comparative case study of two middle school communities where the first author spent over 300 hours observing and interacting with the adult school-based workforces in 2013-15. In addition to observing school practices, she shadowed workers, 
interacted and participated in school events, and conducted interviews and short surveys with purposefully selected staff. To capture the textually mediated organization of labor at a system level, as Acker recommends, job descriptions, employee handbooks, and evaluation frameworks from the case study schools and the school district, and administrative data on the composition of jobs in the district as a whole were also collected.

The two case study schools are both small New York City middle schools (6- $8^{\text {th }}$ grades) with slightly above average test scores and slightly below average economic need compared to the district as a whole. In each of these schools, more than 75 percent of students identify as African American, Hispanic, or Asian, more than 60 percent of students qualify for free and reduced lunch, more than 35 percent meet state standards in English, and over 80 percent of students report feeling safe. Both therefore represent successful urban schools managing substantial poverty and racialized marginality among their students.

Although only $11 \%$ of the students at Riverside ${ }^{1}$ were White, $57 \%$ (8 of 14 ) teachers were White; at Parkview, $19 \%$ of the students but $75 \%$ of the teachers (22 of 29) were White. None of the paraprofessionals at either school were White. The schools were selected purposively to facilitate comparison by gender: at Riverside, a slightly smaller school, more than 65 percent teachers are men and all the administrators are women, while at Parkview 65 percent of teachers are women and all the administrators are men. Riverside and Parkview are neither average NYC schools nor typical U.S. public schools. What the case study schools allow us to see, however, is how school work is organized and valued under relatively "good" conditions, that is, in school communities where workers regularly and successfully interact along differences of race, class, gender, age, and ability.

\footnotetext{
${ }^{1}$ Throughout this article, pseudonyms are used for participants and places.
} 
The fieldwork in both schools revealed that there were also meaningful differences in how they organized the work of teaching. Riverside describes itself as using both "the best traditional teaching methods and new technology." The school favors "traditional" teaching and learning, with teachers positioned as knowledge bearers, and emphasizes success in the state examinations. Classrooms are essentially the individual fiefdoms of teachers (the so-called eggcrate model) and paras and teachers interact primarily within the confines of the classroom. In contrast, Parkview has a palpable tech-startup and anti-establishment vibe. Meetings between teaching staff, which are frequent, always involve taking notes on a shared GoogleDoc with changes jointly made in real time. Classrooms have plenty of colorful beanbag chairs for students to relax in while they read, and it is more common for staff to wear fitted t-shirts with funky sayings than blazers and slacks. The principal credits his readiness to push back against district rules and policies as part of what makes the school great. Although both schools are "screened" public schools, with some control over their own admissions, Parkview -- unlike Riverside -- does not use test scores in making these decisions.

In sum, Riverside is a traditionally organized school with an unconventionally large proportion of male teachers; Parkview is a more collectively organized school with a more conventional reliance on White female teachers. Both schools have a majority of non-White students and a majority of White teachers; all paraprofessionals at both schools are non-White but Parkview, unlike Riverside, includes men as well as women of color.

In looking at these schools as particular regimes of inequality, both their similar location in the US and NYC organization of schools as workplaces and their differences in how they organize work in their individual sites matter in how they mobilize gender, race and class to reproduce and contest inequalities. In the following three sections, we weave concern with racial 
hierarchy into the contested reliance on credentialism in staffing schools, the contested and changing meaning of "support" as a struggle over the relationship between skill and care in schools, and the local variation in NYC schools' use of paraprofessionals to see the overall inequality regime.

\section{Credentialism}

The striking mismatch between an overwhelmingly White and middle-class teaching workforce, and an increasingly immigrant, working-class, and minority student population is not distinctive for these two schools but has characterized urban school systems since the late 1960s. Paraprofessionals, unlike teachers, have historically resembled the student population in racial, ethnic, and class backgrounds. Paras today, as in the 1960s when they first entered public schools, are majority Black and Latina women who live near the community in which they work (Haring, Saren, Lovett, \& Shelton, 1992; Kaplan, 1977; Lewis, 2005). Therefore, paras are often the only adults of color working directly with students in schools.

Teachers and parents resisted the first paid paraprofessionals, fearful that uncertified adults working directly with students would undermine educational standards and lower teachers' salaries (Bowman \& Klopf, 1968; Gartner, Jackson, \& Riessman, 1977). Teachers should have the same status as doctors and lawyers, they said, opining that: "The modern executive has assistants; the dentists and the doctors have assistants. Why can't the teacher have assistants and be relieved of some purely mechanical duties?" (Carroll, 1956, p. 146). Teachers from the start drew a bright boundary around instructional tasks as their singular domain and continue to defend that distinction today, even though demonstration projects from the 1960s on provided compelling evidence that an education credential did not fully capture the skills 
educators needed to be effective with students and communities, but instead maintained an unnecessary class-based system of exclusion (Gartner, 1971).

The New York City teachers' union (United Federation of Teachers) has represented both teachers and paras since 1969; however, they have continued to insist on the initial provision that "paraprofessionals always work under the direct supervision of a licensed teacher" (American Federation of Teachers, 1977, p. 6). A college degree and a specific teaching credential is always required to be a teacher, but paras need only be high school graduates and pass a proficiency test . The UFT defines educational credentialing as the path to upward mobility for both. Its career ladder program proved to be the City's largest source of minority teacher development, helping as many as 8,000 paras become certified teachers by the late 1990s (Kahlenberg, 2007).

However, facing a fiscal crisis, NYC laid off 4,000 paraprofessionals in 1975, and put an end to the low-cost CUNY career ladder that had enrolled 6,000 paras a semester (Juravich, 2015, 2016). On average, paras earn half as much as teachers. During the 2013-2014 school year, the median salary for paras was $\$ 31,161$ and the maximum was $\$ 38,312$, while teachers earned a median of $\$ 73,449$ and their minimum was $\$ 45,530$, thus guaranteeing teachers a pay advantage even if the para has considerably more experience. Contracts specifying continuing education requirements now place the onus on the teachers and paras to choose, complete, and often pay for higher education.

The subordinate role of the para in "instruction" is underlined by teachers' not including them in the curriculum planning meetings, even though the paras are expected to anticipate and support the teacher's activities in the classroom. In the more collaborative Parkview school, exclusion takes the form of not allocating any space for the paras to call their own, meaning that they need to carry belongings like handbags from classroom to classroom as they rotate among 
teachers and projects. Working with the more tradition-minded and gender-integrated teaching staff of Riverside, paras have a "home" classroom but find their instructional help for students denigrated as undermining the students' independence and interfering with their learning. When paras use their experience with learning difficulties to suggest innovative ways to help all students learn, their contributions are rebuffed. In neither school are paras accorded respect for their experientially-acquired knowledge.

In sum, skill as a teacher is institutionalized in the form of a teaching credential and additional education in the form of on-going classes and additional degrees are requirements for being evaluated as more skilled. The hierarchy of skill between teacher and para is embedded not only in the different credentials demanded and pay provided, but in the contractual demand that paras work be done under the "direct supervision of a licensed teacher."

\section{Support and care}

The care dimension of work is most obviously institutionalized in the paras' occupational definition as providing "support" to both students and teachers in the classroom. While teachers were more inclined to see support in terms of mechanical and quasi-secretarial tasks, educational policy tended to focus on the paras role in mediating between the demands of the school and the capacities of the students. In the 1960s and 1970s, these needs were conceptualized largely in terms of serving poor communities; recruiting paras from local communities was seen as an appropriate way to recognize the nurturing capabilities of non-employed mothers by converting their unrecognized community and family labor into paid jobs, albeit with sub-subsistence wages (Juravich, 2015; Kaplan, 1977; Lewis, 2004).

The federal Individuals with Disabilities ACT (IDEA), passed in 1975 changed the trajectory of paraprofessional work in the United States. In guaranteeing all students regardless 
of ability-level, "a free and appropriate public education," IDEA demanded support services that teachers alone were ill-equipped to provide. As policy now mainstreamed children with diverse disabilities into special education programming and general education classrooms, the job of the para was redefined as supporting the needs of these students. Today a majority (55\%) of the more than 25,000 NYC public school paras work with special education students or classrooms. Other paras, who continue to work in high poverty schools and with English language learners, are faced with the demands of teachers for support in classroom management and help with children who are "underperforming." By helping only such students, however, the hierarchy by which students are defined as "deficient" is underscored and care is allocated only as a supplement to the "instruction" which teachers alone are authorized to control.

The general education students' ability to get support from paras is largely relegated to spaces in the school outside the classroom. Principals often delegate the work of supervising lunch and recess periods to paras, and paras use the time that is marked off as "non-instructional" to be in more direct contact with the students and identify those who may be struggling with family crises or other non-school needs. Even as the organization of para work is more focused on helping disabled or low-performing students meet the teachers' goals in the classroom, the institutional division of the school day into instructional and non-instructional time and spaces places the work of care largely in the non-instructional domain.

Unsurprisingly, paras value this lower status work in non-instructional time and space as an important part of their jobs and essential to their relationships with students. For example, a longtime Parkview para, Incocenio Cuesta, often pulls students aside during lunch, recesses, or passing time to have personal conversations, noting that, "educators forget and [the] principal forgets that no one's really touching base with these kids. . . say something happened in school 
and they just need something, they're not getting it from the teachers in the classroom”. As a para, he said, "I can take that opportunity during transition from one classroom to another if I ever need to, you know, hold out a kid for like five minutes and write a pass" (Interview, May 6, 2015).” And Tracy Stone, a Riverside para, kept a personal record of student attendance and publically recognized and hugged students when they attended class for a month straight. Paras, therefore, emphasize their knowledge of the students as people with a variety of strengths and challenges and the rewards of helping them succeed in school.

\section{Respect for moral worth}

The third dimension of the inequality regime organizes the work of drawing boundaries within the school that are more or less morally inclusive of all participants as full members. For example, when the families of students with disabilities succeeded in having national policy (IDEA) recognize these children as part of the public school community, this policy also furthered the broader claims on citizenship and moral worth for people with different physical and mental abilities in society. However, as the work of paras has shifted institutionally to focus more on special education, their role in contesting as well as reproducing the racial stratification of schools, in NYC and elsewhere, has been less acknowledged as critical work for school success. Racial boundaries are visible in schools and so crossing these boundaries demands work to create a more integrated community and achieve more than a superficial appearance of diversity. As successful schools, both Riverside and Parkview offer examples not only of how racialization pervades the system but how this inequality regime is challenged by paras' work to produce respect and dignity for all.

The local community recruitment that brings paras into school employment means that they are much closer to the students with whom they work not only by virtue of their shared 
membership in Black or Hispanic racial categories but also by not commuting from the distances that teachers cover, and in belonging to community associations along with parents and others from these neighborhoods. Paras' location "in the community" and their racial similarity to the students and difference from most teachers also elicits boundary work from both teachers and paras.

On the one hand, the minority of teachers who are men or women of color are recognized by the paras as making special efforts to include them. A Parkview teacher of color offered the paras opportunities to keep their things in his classroom, for example, and at Riverside, a teacher of color picked a para to partner with over fellow teachers for a scavenger hunt during a staff inservice day. On the other hand, paras felt obligated to mediate and prevent racial misunderstandings among teachers, between teachers and paras, and students and their teachers. During the 2014-2015 school year after the non-indictment of police officers who killed NYC resident, Eric Garner, this took the form of male paras sharing their personal experiences with police brutality to educate White teachers about the racialized experiences of people of color in the City. Similarly, Corrie Vines, a longtime resident of the school community shared Peggy McIntosh's "Invisible Backpack" article with the principal in an effort to spur schoolwide conversations on race and privilege. Therefore, while paras sometimes found allies in teachers of color, they also expanded their job responsibilities to include educating staff about racial inequalities.

Additionally, the paras understood the responsibilities of their job to include instilling racial pride in the students at each school. For Jeanine Teston, a Black para, this included intervening in conversations among girls of color bemoaning their appearance, to tell them that "all hair is good hair," and to show them pictures of herself and family with a range of hair 
textures and styles. Using non-instructional time at lunch or recess to offer encouragement or to praise students for accomplishments not reflected in test scores was a way that paras contested the discourse of "racial disparity" in the school system - and American education overall -- that defined testing as the true measurement of student value. Jeanine saw her place in school as offering struggling students refuge from feelings of failure, remarking, "when I was in school, I kind of wish that there was more people in the school who had no problem with saying it's okay. So I appreciate the fact that I am that person in the school that gets to do that, like, for those students who need that, and we laugh" (Interview, March 23, 2015). By valuing their own work and resisting the credentialism that the system demanded for their "progress" toward becoming teachers, the paras also contested the measurement of worth in terms of paychecks and social power more generally. Working in and for their communities was something that the paras affirmed as valuable for themselves and for their students, making "racial uplift" along with "interracial understanding" part of the respect-claiming labor they provided.

\section{Conclusions and challenges}

This research foregrounds the significant but often overlooked contributions of paraprofessionals in schools, and the intersectional inequality regime that organizes their recruitment, rewards and interactions at all levels from macro to micro. These public school employees are majority Black and Latina and perform essential but devalued work in U.S. school communities. As Acker suggested, their work is structurally organized, evaluated and actually done in relation to the class, gender, and race meaning of workers seen as ideal incumbents. Nonetheless, while school employees are rewarded for solely academic credentials and held most accountable for narrowly defined test outcomes, they are expected to provide much more, not only nurturance for individuals, especially those defined as in special need, but also building a 
community in which members feel belonging, and engendering a sense of self-esteem and accomplishment in students. The work of producing respect and dignity demands racialized labor to contest boundaries that produce definitions of inferiority and practices of exclusion.

Because the focus on academic achievement defined as test scores and rewarded "meritocratically" has greatly increased in recent years, it is structurally more difficult for teachers and paras to collaborate, students do not always receive the care and racial socialization they need, and the career trajectory of paras has become less desirable. Paras see teachers as overwhelmed with grading and testing, as having fewer opportunities to relate to their students in the classroom in non-evaluation-centered ways, and as forced into competitive relations with other schools. By taking the perspective and position of the paraprofessional workforce more seriously, the overall inequality regime of the school comes into clearer focus. 


\section{References}

Acker, J. (1990). Hierarchies, jobs, bodies: A theory of gendered organizations. Gender \& Society, 4(2), 139-158.

Acker, J. (2006). Inequality regimes: Gender, class, and race in organizations. Gender \& Society, 20(4), 441-464. https://doi.org/10.1177/0891243206289499

American Federation of Teachers. (1977). Organizing paraprofessionals: A manual prepared by the committee on paraprofessionals. Washington, D.C.: AFL-CIO.

Apple, M. W. (1986). Teachers and texts: A political economy of class and gender relations in education. New York: Routledge \& Kegan Paul.

Bowman, G. W., \& Klopf, G. J. (1968). New careers and roles in the American school. New York: Bank Street College of Education.

Brockenbrough, E. (2012). Emasculation blues: Black male teachers' perspectives on gender and power in the teaching profession. Teachers College Record, 114(5), 1-43.

Carroll, L. (1956). The Bay City Experiment . . . as seen by a classroom teacher. Journal of Teacher Education, 7(2), 142-147.

Choo, H. Y., \& Ferree, M. M. (2010). Practicing intersectionality in sociological research: A critical analysis of inclusions, interactions, and institutions in the study of inequalities. Sociological Theory, 28(2), 129-149. https://doi.org/10.1111/j.1467-9558.2010.01370.x

Collins, A. (1998). Mothers as teachers-teachers as mothers. In S. Abbey \& A. O’Reilly (Eds.), Redefining motherhood: changing identities and patterns. (pp. 92-102). Toronto: Second Story Press.

Crenshaw, K. (1989). Demarginalizing the intersection of race and sex: A black feminist critique of antidiscrimination doctrine, feminist theory and antiracist politics. The University of 
Chicago Legal Forum, (1), 139-168. Retrieved from

http://chicagounbound.uchicago.edu/uclf/vol1989/iss1/8

Dingus, J. E. (2008). “Our family business was education”: Professional socialization among intergenerational African-American teaching families. International Journal of Qualitative Studies in Education, 21(6), 605-626. https://doi.org/10.1080/09518390701470313

Dixson, A. D. (2003). “Let's Do This!”: Black women teachers' politics and pedagogy. Urban Education, 38(2), 217-235. https://doi.org/10.1177/0042085902250482

Dixson, A. D., \& Dingus, J. E. (2008). In search of our mothers' gardens: Black women teachers and professional socialization. Teachers College Record, 110(4), 805-837.

Duffy, M. (2011). Making care count: A century of gender, race, and paid care work. New Brunswick: Rutgers University Press.

Dwyer, R. E. (2013). The care economy? Gender, economic restructuring, and job polarization in the U.S. labor market. American Sociological Review, 78(3), 390-416. https://doi.org/10.1177/0003122413487197

England, P. (1992). Comparable worth: Theories and evidence. New York: Aldine.

England, P. (2005). Emerging theories of care work. Annual Review of Sociology, 31(1), 381399. https://doi.org/10.1146/annurev.soc.31.041304.122317

England, P., Budig, M., \& Folbre, N. (2002). Wages of virtue: the relative pay of care work. Social Problems, 49(4), 455-473. https://doi.org/10.1525/sp.2002.49.4.455

Fisher, B. M. (2001). No angel in the classroom: Teaching through feminist discourse. New York: Rowman \& Littlefield Publishers.

Foster, M. (1993). Educating for competence in community and culture: Exploring the views of exemplary African-American teachers. Urban Education, 27(4), 370-394. 
https://doi.org/10.1177/0042085993027004004

Frankenberg, E., \& Orfield, G. (Eds.). (2012). The resegregation of suburban schools: A hidden crisis in American education. Cambridge, Mass.: Harvard Education Press.

Gartner, A. (1971). Paraprofessionals and their performance: A survey of education, health, and social service programs. New York: Praeger Publishers, Inc.

Gartner, A., Jackson, V. C., \& Riessman, F. (Eds.). (1977). Paraprofessionals in education today. New York: Human Sciences Press.

Glenn, E. N. (1992). From servitude to service work: Historical continuities in the racial division of paid reproductive labor. Signs, 18(1), 1-43.

Glenn, E. N. (1999). The social construction and institutionalization of gender and race. In M. M. Ferree, J. Lorber, \& B. B. Hess (Eds.), Revisioning gender (pp. 3-43). Thousand Oaks, Calif.: Sage Publications.

Hansen, P., \& Mulholland, J. A. (2005). Caring and elementary teaching: The concerns of male beginning teachers. Journal of Teacher Education, 56(2), 119-131. https://doi.org/10.1177/0022487104273761

Haring, K. A., Saren, D., Lovett, D. L., \& Shelton, M. N. (1992). A study of the demographic and attitudinal differences between paraprofessionals and teachers in self-contained special education classrooms. Journal of Developmental and Physical Disabilities, 4(1), 51-73. https://doi.org/10.1007/BF01046341

Ingersoll, R. M. (2003). Who controls teachers' work?: Power and accountability in America's schools. Cambridge, Mass.: Harvard University Press.

Ingersoll, R. M., Merrill, L., \& Stuckey, D. (2014). Seven trends: The transformation of the teaching force, updated April 2014. CPRE Report (\#RR-80). Philadelphia: Consortium for 
Policy Research in Education, University of Pennsylvania.

James, J. H. (2010). Teachers as mothers in the elementary classroom: Negotiating the needs of self and other. Gender and Education, 22(5), 521-534.

https://doi.org/10.1080/09540250903519436

Juravich, N. (2015). Paraprofessional educators and labor-community coalitions, past and present. The Labor and Working Class History Association. Retrieved from https://www.lawcha.org/2015/02/24/paraprofessional-educators-and-labor-communitycoalitions-past-and-present/

Juravich, N. (2016). Making a "Paraprofessional Movement" in New York City. (P.-C. Aigner, Ed.). New York Ciy: The Gotham Center for New York City History Blog. Retrieved from http://www.gothamcenter.org/blog/making-a-paraprofessional-movement-in-new-york-city

Kahlenberg, R. D. (2007). Tough liberal: Albert Shanker and the battles over schools, unions, race, and democracy. New York: Columbia University Press.

Kaplan, G. R. (1977). From aide to teacher: The story of the Career Opportunities Program. Washington, D.C.: U.S. Department of Health, Education, and Welfare.

Kennelly, I. (1999). “That single-mother element”: How White employers typify Black women. Gender \& Society, 13(2), 168-192. https://doi.org/10.1177/089124399013002002

Kilbourne, B. S., England, P., Farkas, G., Beron, K., \& Weir, D. (1994). Returns to skill, compensating differentials, and gender bias: Effects of occupational characteristics on the wages of White women and men. American Journal of Sociology, 100(3), 689-719. https://doi.org/10.1086/230578

Ladson-Billings, G. (1994). The dreamkeepers: Successful teachers of African American children. San Francisco: Jossey-Bass Publishers. 
Lamont, M. (2000). The dignity of working men: Morality and the boundaries of race, class, and immigration. Cambridge, Mass.: Russell Sage Foundation.

Lewis, K. C. (2004). Instructional Aides: Colleagues or Cultural Brokers? School Community Journal, 14(1), 91-112.

Lewis, K. C. (2005). Seen but not heard: ESEA and instructional aides in elementary education. Review of Research in Education, 29(1), 131-149. https://doi.org/10.3102/0091732X029001131

Lortie, D. (1975). School teacher: A sociological study. Chicago: University of Chicago Press.

Lynn, M. (2006). Education for the community: exploring the culturally relevant practices of Black male teachers. Teachers College Record, 108(12), 2497-2522.

Martin, P. Y. (2003). "Said and done" versus "saying and doing" gendering practices, practicing gender at work. Gender \& Society, 17(3), 342-366. https://doi.org/10.1177/0891243203251716

Moss, P., \& Tilly, C. (1996). "Soft” skills and race: an investigation of Black men's employment problems. Work and Occupations, 23(3), 252-276. https://doi.org/10.1177/0730888496023003002

Orfield, G., \& Lee, C. (2005). Why segregation matters: Poverty and educational inequality. Cambridge, Mass.: The Civil Rights Project, Harvard University.

Pierce, J. L. (1995). Gender trials: Emotional lives in dontemporary law firms. Berkely: University of California Press.

Ridgeway, C. L. (2014). Why status matters for inequality. American Sociological Review, 79(1), 1-16. https://doi.org/10.1177/0003122413515997

Snyder, T. D., de Brey, C., \& Dillow, S. A. (2016). Digest of education statistics, 2015 (NCES 
2016-014). Washington, D.C.: National Center for Education Statistics, Institute of Education Sciences, U.S. Department of Education.

Steinberg, R. J. (1990). Social construction of skill: Gender, power, and comparable worth. Work and Occupations, 17(4), 449-482. https://doi.org/10.1177/0730888490017004004

Vincent, C., \& Braun, A. (2012). Being "fun" at work: Emotional labour, class, gender and childcare. British Educational Research Journal, 39(4), 1-18. https://doi.org/10.1080/01411926.2012.680433

Wingfield, A. H., \& Alston, R. S. (2013). Maintaining hiehrarchies in predominantly White organizations: A theory of racial tasks. American Behavioral Scientist, 58(2), 1-14. https://doi.org/10.1177/0002764213503329 